Supplement of Atmos. Chem. Phys. Discuss., 15, 31025-31051, 2015

http://www.atmos-chem-phys-discuss.net/15/31025/2015/

doi:10.5194/acpd-15-31025-2015-supplement

(C) Author(s) 2015. CC Attribution 3.0 License.

(c) (i)

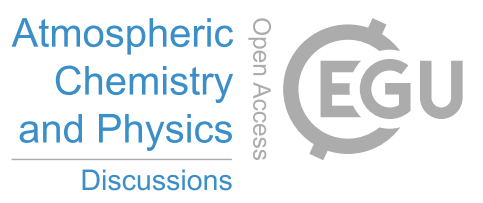

Supplement of

\title{
A Joint data record of tropospheric ozone from Aura-TES and MetOp-IASI
}

\section{H. Oetjen et al.}

Correspondence to: V. H. Payne (vivienne.h.payne@jpl.nasa.gov)

The copyright of individual parts of the supplement might differ from the CC-BY 3.0 licence. 


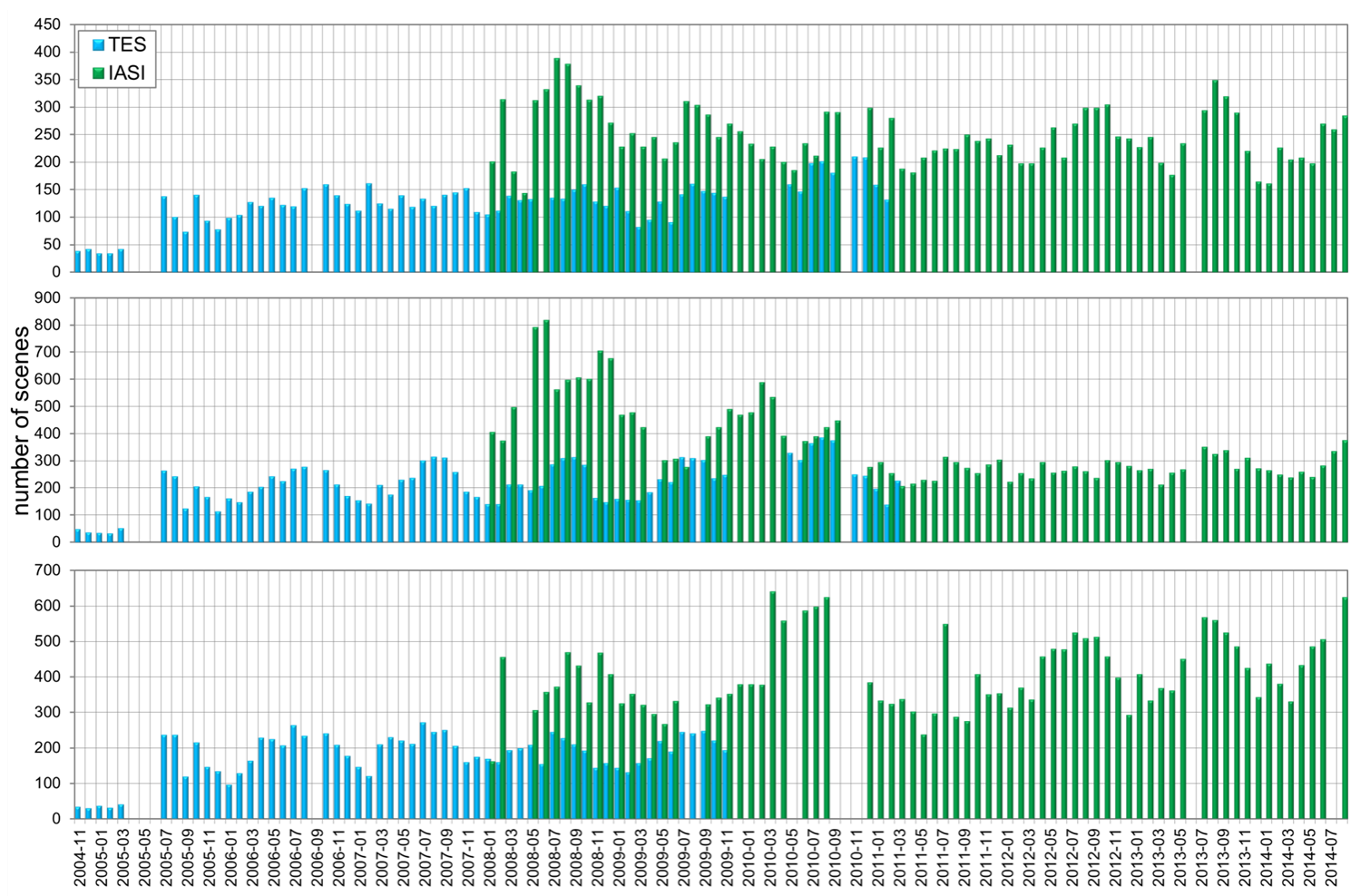

1

2 Figure S1. Number of satellite data points included for the calculation of the monthly mean 3 ozone for Fig. 7. 